\title{
An Evaluation of Mutual Fund Performance in an Emerging Economy: The Case of Pakistan
}

\section{Mahreen Mahmud ${ }^{*}$ and Nawazish Mirza ${ }^{* *}$}

\begin{abstract}
This article examines the performance of Pakistan's mutual fund industry during 2006-10, a period characterized both by bullish and bearish markets. An analysis of fund types reveals that Islamic funds have shown strong growth in spite of their lackluster performance compared to conventional funds. Income funds appear to have suffered as a consequence of the underdeveloped bond market, and very high t-bill rates have resulted in negative excess returns during the period. For stock funds, market indices and size are significant factors that indicate a preference for large-cap stocks of managers. With consistently negative or insignificant alphas, no fund manages to outperform the market.
\end{abstract}

Keywords: Mutual Funds, Fund Performance, Pakistan.

JEL Classification: G23, G11.

\section{Introduction}

The ability of mutual funds to outperform the market has long been the subject of debate in the literature, particularly with reference to the developed world. The debate was fuelled in the 1990s with the phenomenal growth of the mutual fund industry across the developed world, with annual growth rates for mutual fund net assets averaging 22.4 percent in the US and 17.7 percent in the European Union (Klapper, Sulla, \& Vittas, 2004). This was seen in the light of the rapid globalization of financial markets and unprecedented growth in market capitalization. A well-developed securities market and an effective regulatory framework are therefore seen as the backbone of growth in the mutual fund industry.

Pakistan's financial sector became more liberalized in the 1990s as private players were allowed to enter the market, but the 2000s saw a

\footnotetext{
${ }^{*}$ Research and Teaching Fellow, Centre for Research in Economics and Business, Lahore School of Economics.

** Associate Professor of Finance, Centre for Research in Economics and Business, Lahore School of Economics.
} 
groundbreaking change. The strong surge in domestic and international investors' interest in Pakistani stocks at the start of the millennium set the stage for the growth of the country's mutual fund industry. Today, mutual funds are the dominant nonbanking finance institutions (NBFIs) in the country. The impetus came as the Investment Corporation of Pakistan was privatized in 2000 and the regulation of NBFIs was handed over to the Securities and Exchange Commission of Pakistan. ${ }^{1}$

Despite its strong growth, the mutual funds industry remains a small part of the stock market-at the end of the fiscal year (FY) 2010, it comprised 6.1 percent of the total market capitalization of the Karachi Stock Exchange (KSE) and less than 5 percent of banking industry deposits (in advanced economies, the size of mutual funds exceeds banking deposits). Its future prospects and place within the country's underdeveloped capital market make it a relevant study subject. Growth in the industry can be indicative of increased investor interest, and raises interesting questions about the impact of more conventional alternatives-particularly depositor behavior in the banking industryon investor behavior.

Here, we attempt to evaluate the performance of mutual funds in Pakistan. Although there are some studies on the subject, our research adds value in several ways. We analyze primarily the industry's performance in a period that witnessed a rapid rise both in asset management companies (AMCs) and their respective mutual funds. All previous studies span periods prior to 2006, when there were only a few asset managers with a moderate number of funds. Moreover, there has been a significant change in the dynamics of the KSE since 2006. We have witnessed an increase in turnover with periods of extreme volatility. There were periods when bulls dominated the markets, and instances where the KSE was caught in a bear trap. This high volatility was partly responsible for fueling the growth of mutual funds in Pakistan, and presents an opportunity to analyze their performance in both bull and bear markets. The significantly large number of mutual funds makes it possible to carry out a fund-wise analysis, which has not been done before. Lastly, we use more sophisticated empirical and methodological measures to report more robust findings.

The rest of the article is organized as follows. Section 2 briefly examines the mutual fund industry in Pakistan. Section 3 reviews some of

\footnotetext{
${ }^{1}$ This is currently regulated under the Non-Banking Finance Companies and Notified Entities Regulations, 2008.
} 
the existing literature on the subject. Section 4 presents the study's data. Section 5 builds an empirical methodology. Our empirical results are reported in Section 6, and Section 7 concludes the study.

\section{Characteristics of the Pakistani Mutual Fund Industry}

During FY2001-10, the number of open-ended funds in Pakistan grew to about 30 by FY2005, after which there was a more-than-threefold increase to 105 funds by FY2010 (Mutual Funds Association of Pakistan [MUFAP], 2010) (Figure 1). Even though the number of AMCs has remained stagnant in the last three years, their funds continue to grow rapidly. This comes despite a dramatic drop in the industry's net asset value (NAV) as the worldwide recession hit Pakistan's capital market in 2008. The NAV rose up until 2008 (to PKR278.9 billion) but has since declined dramatically to PKR167.7 billion in 2010. This is indicative of the impact of the financial crisis, which has affected investments in mutual funds and the value of assets held by these funds.

Figure 1: Evolution of AMCs and Funds in Pakistan (FY2001-10)

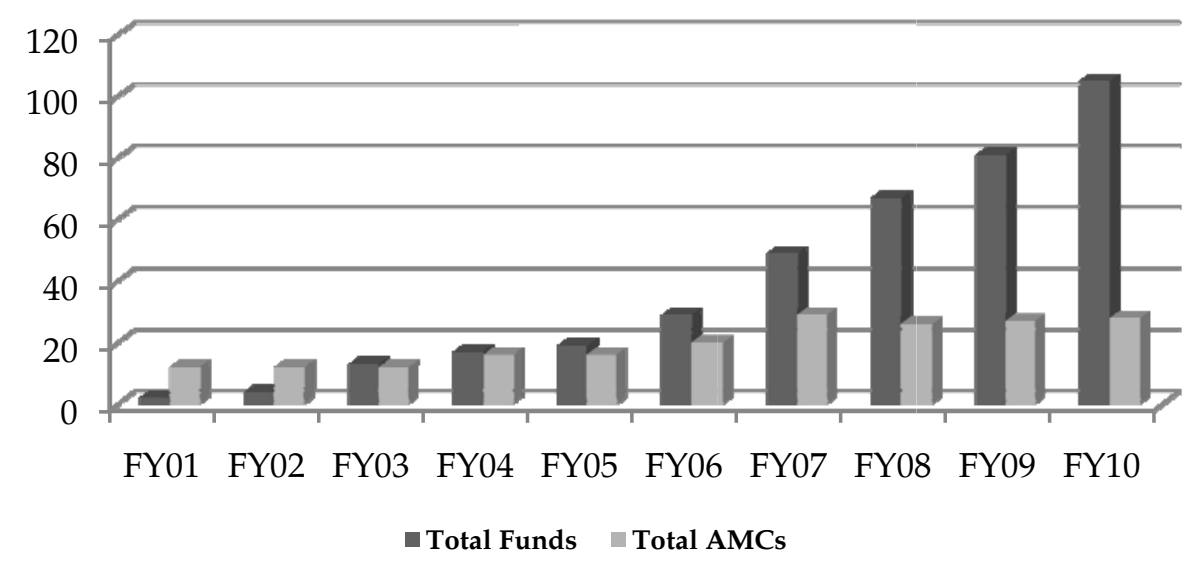

$\mathrm{AMC}=$ asset management company, $\mathrm{FY}=$ fiscal year.

Source: Mutual Funds Association of Pakistan.

Thus, the last half of FY2001-10 is an interesting period during which the mutual fund industry experienced both a period of particularly high growth as well as the effects of a worldwide recession. This makes it an important period over which to evaluate the industry's performance.

The industry's growth has resulted in the evolution of a variety of funds that specialize in investment styles and cater to various investor needs. A look at how the net asset holding of these funds has evolved in 
the past five years gives us an indication of the changing dynamics of the young industry (Figure 2). Islamic funds have consistently and steadily increased in terms of NAV, and the number of Islamic funds in the country has grown phenomenally (its growth averaging 64 percent over a five-year period). The NAV of income funds, which experienced considerable growth up until FY2008, has since declined dramatically. These funds were the most impacted by the devaluation of term finance certificates (TFCs) during the slowdown of 2008 and appear to have been unable to recover from the shock. Interestingly, money market fundswhich held a negligible share of the market at the time of the crisis-have since shown tremendous growth, particularly their NAV, which almost equaled that of stock and income funds by December 2010.

Figure 2: Fund-Wise NAV (FY2006-10)

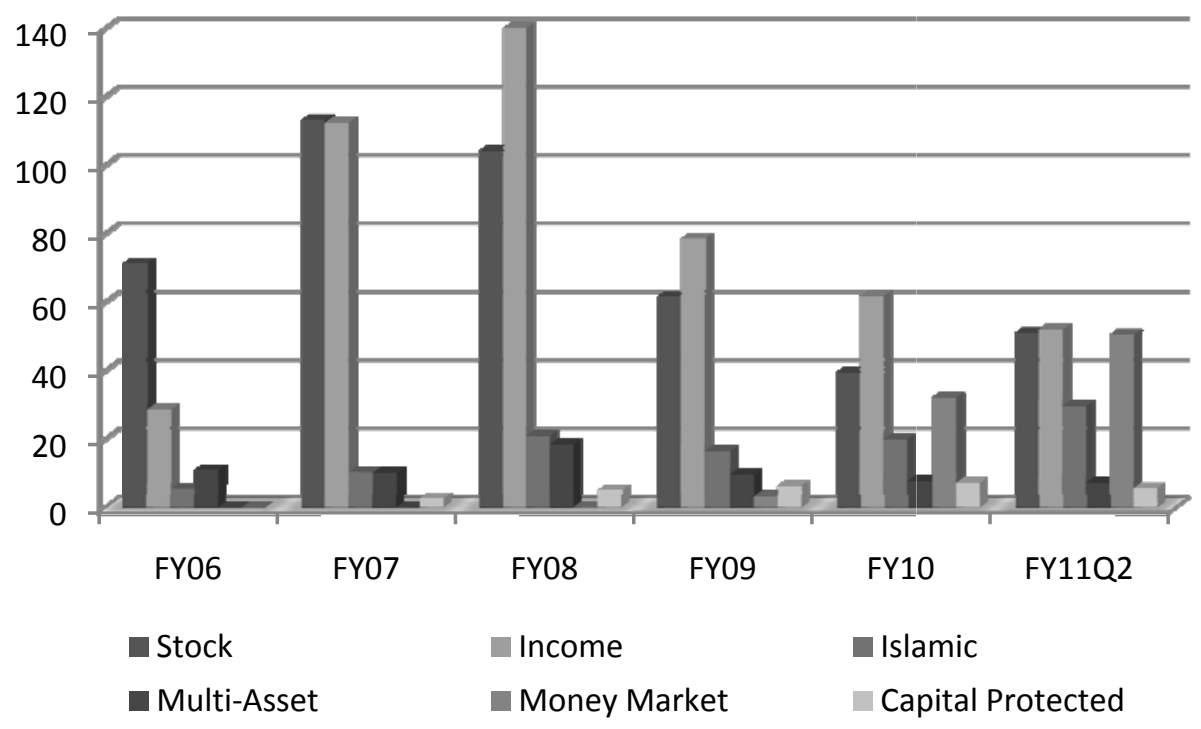

FY = fiscal year, NAV = net asset value.

Source: Mutual Funds Association of Pakistan.

Differences in the risk exposure of different funds (Figure 3) as determined by their investment styles warrants an in-depth look at the performance of each fund separately, an analysis that has not yet been carried out for Pakistan. 


\section{Figure 3: Fund-Wise Risk-Return Exposure}

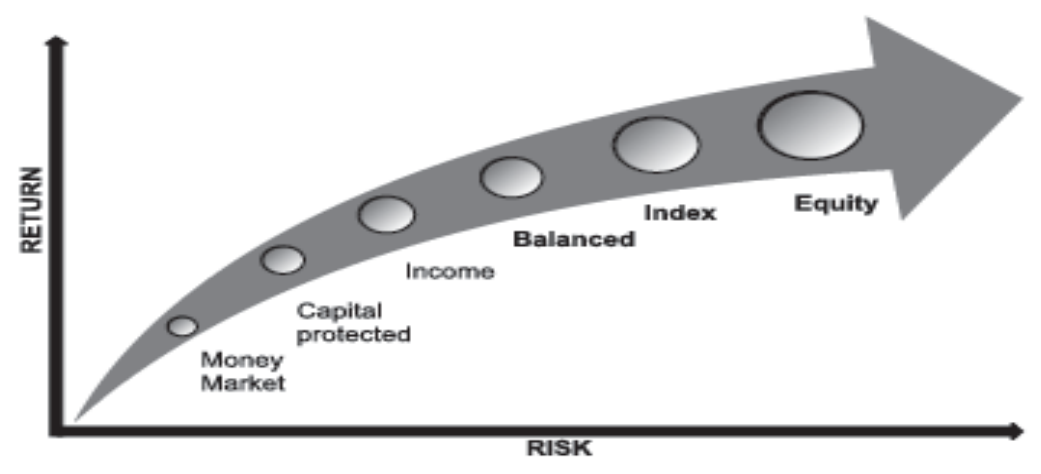

\section{Literature Review}

There is a plethora of literature on the mutual fund industry of the developed world, where such funds have been an important part of the capital market since the 1960s. The literature on mutual funds can be divided broadly into two streams: (i) one evaluates the performance of mutual fund industries relative to other comparable investment opportunities in the economy, and (ii) the other tries to identify significant fund-specific characteristics that result in these returns. We concentrate on the first category.

Seminal studies evaluating the performance of mutual funds arose as early as the 1960s with Jensen (1968) and Sharpe (1966) who used the Sharpe ratio and the one-factor capital asset pricing model (CAPM) to determine mutual fund underperforming market benchmarks. Recent work in the asset-pricing literature by Fama and French (1993) and Carhart (1997) has expanded the traditional one-factor models to account for varying styles of fund managers investing in the stock market. The common consensus in the literature concerns the mixed ability of funds to outperform the market in the case of the developed world (see Cesari \& Panetta, 2002). This has triggered debates about the most effective evaluation techniques. For this reason, Otten and Bams (2004) discuss in detail the relative efficiency of the various traditional techniques employed in the literature, using survivor bias-free data on US equity funds from 1962-2000. They find evidence of the superiority of Carhart's four-factor model in an unconditional setting in explaining mutual fund performance. Recent discussions have extended to using bootstrap simulation techniques in post-estimation evaluations to ascertain whether individual fund managers' skills or luck drive mutual fund performance (see Cuthbertson, Nitzsche, \& O'Sullivan, 2008; Fama \& French, 2010). 
Evidence on emerging countries largely corroborates the findings on the developed world. Using the standard techniques developed in the literature, studies find mixed evidence concerning the developing world but consistently confirm that the four-factor Carhart model adds significant value to understanding mutual fund returns (see Bialkowski \& Otten, 2011; Eling \& Faust, 2010; Huij \& Post, 2011; Lai \& Lau, 2010). For Pakistan, specifically, given the small size of the mutual fund industry, it is not surprising that there are only a handful of studies on the country. The latest studies by Afza and Rauf (2009) and Nazir and Nawaz (2010) both concentrate on finding the determinants of mutual fund performance. Afza and Rauf attempt to understand and explain openended mutual fund performance for the 1999-2006 period as indicated by a quarterly Sharpe ratio. They find very few factors that appear to be significant, and the results point to the importance of past returns predicting future returns while other factors such as expense ratios or the fund's asset size are not significant. Nazir and Nawaz, on the other hand, focus on a very small sample of 13 mutual funds where there is family or group ownership, and try to identify important factors that determine the growth of the industry. They find that asset size does have a positive impact on performance, as do management fees.

Sipra (2006) and Shah and Hijazi (2005) use KSE-100 as a benchmark to evaluate mutual fund returns up to 2004, and are therefore the most pertinent to our study. Sipra concludes that performance has been quite poor over this period and that only 30 percent of funds could in a subperiod outperform the market portfolio. Shah and Hijazi find evidence of funds outperforming the market but this could be due to the restricted sample of funds employed in their study as compared to Sipra. Since no study has looked at mutual fund performance after the industry's recent phenomenal growth, it would be interesting to see if this trend has been reversed. Several different funds have evolved in Pakistan and, given their number, it is now possible to conduct an evaluation according to fund type. Further, other studies have so far been restricted to the relatively simple Sharpe and Treynor measures for analysis.

\section{Data}

The sample period spans January 2006 to December 2010, and is characterized both by bullish and bearish markets. We have chosen this sample period given (i) the tremendous growth both in the number of funds in Pakistan and their investment levels, and (ii) that all previous literature on mutual funds in the country is restricted to the pre-2006 period during which 
only modest growth occurred. A study evaluating the performance of mutual funds in this new phase of rapid growth is therefore pertinent.

Monthly data on the NAV of each fund was collected from their respective websites. Each fund had been in operation for at least 12 months for our sample period. We thus have 86 funds in our sample distributed among five categories ${ }^{2}$ (Table 1). The risk-free rate for the country (three-month t-bill rate) and the benchmark indices KSE-100, KSE-30, and Pakistan investment bonds (PIBs) rate were obtained from the Financial Markets Association of Pakistan (retrieved from http://www.fma.com.pk). To evaluate Islamic funds, the Dow Jones Islamic Market Pakistan Index for the sample period was obtained by request from Dow Jones Indexes. To apply the Fama-French three-factor CAPM, the book-to-market ratio, market value (MV), and price of each listed company was obtained from Thomson Reuters Datastream.

The literature points to the issue of survivorship bias whereby excluding dead funds leads to overestimating the returns (see Carhart, Carpenter, Lynch, \& Musto, 2002). This is because the performance of funds that are now dead would have been worse than that of the funds that survived. However, in Pakistan's case, there is no central database that maintains a record of all funds, so it was not possible to obtain data on these funds and we have had to rely on data on the surviving funds alone.

Table 1: Average Annual Returns (\%)a

\begin{tabular}{lrrrrr}
\hline & Stock & Islamic & Income & $\begin{array}{c}\text { Multi- } \\
\text { Asset }\end{array}$ & $\begin{array}{c}\text { Money } \\
\text { Market }\end{array}$ \\
\hline No. of funds & 18 & 20 & 28 & 12 & 8 \\
2006 & -25.64 & -7.90 & -2.43 & -18.15 & - \\
2007 & 25.56 & 8.58 & 4.67 & 10.61 & - \\
2008 & -44.43 & -25.92 & -9.06 & -42.06 & 0.04 \\
2009 & 51.87 & 27.77 & 8.40 & 41.16 & 2.83 \\
2010 & -2.17 & 0.02 & -1.16 & -8.15 & 1.11 \\
$2006-07$ & -0.02 & 0.00 & 0.01 & -0.04 & - \\
$2009-10$ & 0.27 & 0.13 & 0.03 & 0.14 & 0.02 \\
Period average (excl. 2008) & 0.12 & 0.07 & 0.03 & 0.05 & 0.02 \\
Period average (2006-10) & -0.04 & -0.01 & 0.00 & -0.07 & 0.02 \\
\hline
\end{tabular}

a Annualized returns are computed as the compounded average monthly return for 12 months.

Source: Authors' calculations.

\footnotetext{
${ }^{2}$ We follow the MUFAP classification. Only four capital-protected funds had an inception date prior to December 2009, and were therefore not included as a separate category
} 
All funds managed to register a positive average return for the period if 2008 is excluded, which was undoubtedly a difficult year for an industry still in its infancy (Table 2). It comes as no surprise that stock funds suffered huge losses as the country's premier stock index, the KSE100, registered a 61 percent loss for the year. ${ }^{3}$ The revaluation of TFCs made necessary by high interest rates and liquidity constraints in the banking sector in the last half of 2008 caused further problems for the mutual fund industry as a whole.

\section{Methodology}

We analyze the industry by first employing the standardized and simple Sharpe measure to evaluate the performance of the funds, specifically for cross-fund comparison. The Sharpe ratio is a measure of the reward given for the variability in returns or, in other words, the excess return per unit of risk being taken for the investment made.

The next step is to evaluate the performance of the funds relative to a market benchmark, employing the unconditional CAPM models. Otten and Bams (2004) establish the superiority of the conditional over unconditional models, but given the short sample period, this would have resulted in a significant loss of degrees of freedom. Jensen (1968) introduced the alpha in the CAPM to measure the abnormal return on a portfolio over and above that earned by the portfolio given the market conditions and risk of portfolio:

$$
R_{i}-R_{f}=\alpha_{i}+\beta_{i}\left(R_{m}-R_{f}\right)+u_{i}
$$

Here, $R_{f}$ is the risk-free rate and $R_{i}-R_{f}$ is thus the excess return on the fund $i$ portfolio; $R_{m}-R_{f}$ is the excess return on the benchmark market portfolio where the benchmark is according to a specific fund's investment style; $\alpha_{i}$ is Jensen's alpha, which measures the performance of the fund and the manager's investment ability. The sign and significance of alpha reflect whether mutual funds outperformed the market proxy and vice versa.

Stock and multi-asset fund performance is further evaluated using the Fama-French three-factor model, which accounts for additional risk factors associated with firm size and the book-to-market ratio. This is done by adding the difference in returns on a portfolio that consists of small cap

\footnotetext{
${ }^{3}$ The KSE-100 index dropped from 15,676 to 5,865 in just the last eight months of the year.
} 
stocks and those that contain large cap stocks (SMB), and the difference in returns between a portfolio of high book-to-market stocks and a portfolio of low book-to-market stocks (HML) ${ }^{4}$ to the CAPM equation:

$$
R_{i}-R_{f}=\alpha_{i}+\beta_{i}\left(R_{m}-R_{f}\right)+\beta_{s} S M B_{i}+\beta_{H} H M L_{i}+u_{i}
$$

Carhart (1997) extends this model by allowing for momentumsorted portfolios returns. The model then accounts for four portfolios that might explain the mean return as given by their individual coefficients:

$$
R_{i}-R_{f}=\alpha_{i}+\beta_{i}\left(R_{m}-R_{f}\right)+\beta_{S} S M B_{i}+\beta_{H} H M L_{i}+\beta_{P} M O M_{i}+u_{i}
$$

The additional factor MOM is the difference in returns on a portfolio of past winners and a portfolio of past losers. This is to account for the momentum factor whereby stocks with high returns are bought in anticipation of high returns in the future, and low-return stocks that are sold.

\section{Empirical Results}

Our preliminary analysis relies on the Sharpe ratio, which measures the reward for the risk that investors take. Further, equally weighted portfolio returns for each fund type are compared with the relevant benchmark for the investment style particular to that fund.

The worst performing fund turns out to be income funds, which were unable to yield positive excess returns in any year (Table 2). Following the dramatic losses faced during the recessionary period of 2008, 2009 saw strong recovery and the highest ratios for the period. Money market funds are the lowest risk category of funds and rely primarily on short-term investments to ensure guaranteed returns and high liquidity. Therefore, the reward for these funds cannot be evaluated using excess returns, which makes the CAPM unsuitable as a method of evaluation. These funds were able to sustain their performance through the recession and continued to perform strongly. The managers of these funds target the short term, and investors are driven by the incentive of the operational efficiency of these funds, which helps investors quickly change portfolios.

\footnotetext{
${ }^{4}$ These are rebalanced semi-annually.
} 
Table 2: Sharpe Ratio (\%)

\begin{tabular}{lcccccc}
\hline \multicolumn{1}{c}{ Fund Type } & $\mathbf{2 0 0 6}$ & $\mathbf{2 0 0 7}$ & $\mathbf{2 0 0 8}$ & $\mathbf{2 0 0 9}$ & $\mathbf{2 0 1 0}$ & Period Average $^{*}$ \\
\hline Stock & -0.406 & 0.093 & -0.245 & 0.460 & -0.161 & -0.094 \\
Islamic & -0.201 & -0.011 & -0.559 & 0.363 & -0.346 & -0.187 \\
Income & -0.406 & -0.182 & -0.767 & -0.388 & -1.019 & -0.497 \\
Multi-asset & -0.254 & 0.017 & -0.364 & 0.622 & -0.257 & -0.176 \\
Money market & - & - & 0.101 & 5.798 & 1.060 & 2.097 \\
\hline
\end{tabular}

Note: Sharpe ratio $=\left(R_{i}-R_{f}\right) / \sigma_{i}$ for all funds but money market funds, for which it is $R_{i} / \sigma_{i}$

Source: Authors' calculations.

In order to present an alternative risk reward comparison, we substitute value at risk (VAR) for total risk. VAR is assumed to be a superior measure of risk because it takes the extreme event on the left tail of the distribution, while the standard deviation could be high even if prices are experiencing exceptionally high growth and in such an instance investors would actually be better off.

The Sharpe ratio modified for VAR present similar results in Table 3.

Table 3: Sharpe Ratio Modified for VAR (\%)

\begin{tabular}{lcccccc}
\hline Fund Type & $\mathbf{2 0 0 6}$ & $\mathbf{2 0 0 7}$ & $\mathbf{2 0 0 8}$ & $\mathbf{2 0 0 9}$ & $\mathbf{2 0 1 0}$ & Period Average \\
\hline Stock & -0.390 & 0.165 & -0.554 & 0.679 & -0.184 & -0.153 \\
Islamic & -0.196 & -0.010 & -0.439 & 0.340 & -0.229 & -0.160 \\
Income & -0.252 & -0.113 & -0.408 & -0.284 & -0.497 & -0.287 \\
Multi-asset & -0.288 & 0.017 & -0.515 & 0.683 & -0.244 & -0.198 \\
Money market & - & - & 0.101 & 5.798 & 1.060 & 2.097 \\
\hline
\end{tabular}

$\mathrm{VAR}=$ value at risk.

Source: Authors' calculations.

Next, we carry out a fund-wise analysis using the unconditional CAPM models, which yield varying degrees of goodness of fit. The results (Table 4) show that the alpha term is consistently negative or insignificant or both, pointing to the inability of any fund category to cross its market benchmark. However, the beta term is highly significant and indicates that the chosen benchmarks are important components of the investment portfolios of these funds.

We then compare stock funds that invest entirely in the stock market with the country's most representative index, the KSE-100. Given the small size of the securities market and the number of dormant stocks 
even within the top 100, we also make a comparison with a smaller index based on free-float using the KSE-30 and an index constructed for the top ten traded stocks. ${ }^{5}$ Not surprisingly, the returns on equity funds move in tandem with movements in the KSE, ${ }^{6}$ the country's premier exchange.

Overall, the three-factor model best explains stock fund returns with an SMB factor, showing a significant effect for all benchmarks (Table 4). The momentum and HML factor does not add much to our understanding. This corroborates the evidence found for other developing nations, where these two factors have also proved insignificant (see Bialkowski \& Otten, 2011; Lai \& Lau, 2010). The KSE-30 used as a benchmark in the Fama-French three-factor model yields the highest $\mathrm{R}^{2}$, giving us an indication of stock fund managers' investment preference for large cap stocks. This is also supported by the negative and significant $\beta_{s}$ coefficient. Managers tilt toward low-risk stocks possibly because the industry is in a nascent stage of development and they want to ensure positive returns even if they are low. Highly traded stocks are also riskier than the safer large cap stocks and therefore the synthetically constructed index of the top ten such stocks at the KSE does not explain much variation in stock fund returns. Individually, about 40 percent of stock funds yield a negative return for the period, but when 2008 is excluded, all funds yield positive returns. As for excess return, close to 70 percent yield negative returns for the period while just three of the 18 yield negative excess returns when 2008 is excluded.

There is no bond index for the country, which makes it difficult to evaluate income funds that invest primarily in fixed income instruments. ${ }^{7}$ We try to proxy for it by making use of the three-year PIB rate. The coefficient on the benchmark yields the expected sign where an increase in interest rates causes the debt instruments to decrease in value, and is therefore negatively linked to income fund returns. However, $\mathrm{R}^{2}$ is very low, indicating that changes in the PIB rate cannot explain the changes in income fund returns very well. As discussed, these funds have faced particular difficulty in registering positive excess returns. Evaluated on a fund-wise basis, 40 percent yield negative excess returns for the sample period and, even if 2008 is excluded, 17 percent yield negative returns. As

\footnotetext{
${ }^{5}$ This index is rebalanced semi-annually and is a value-weighted index. For details, see Mahmud and Mirza (2010).

${ }^{6}$ Close to 90 percent correlation of stock fund returns with KSE-100 and KSE-30 returns for the period.

${ }^{7}$ A bond index (PGBI) was launched in 2005 for Pakistan by FMA and Reuters but ceased being reported in the following years.
} 
they are the largest category of funds in the country, this is cause for concern. It could be accounted for by the revaluation of TFCs with rising interest rates-which has had a detrimental impact on the NAV of these funds-and the very high t-bill rate in the country that has made it difficult for these funds to provide a return over and above that rate and attract investment. The national savings scheme certificates issued by the government to the public guarantee very high risk-free streams of income, and are tough competition for income funds.

Finally, we have been able to find a moderate fit for the last two classes of funds. The reason for this is, again, the lack of a representative bond index. Multi-asset funds are hybrid funds and thus often referred to as balanced funds that invest in a mixture of bonds and stocks. Hence, we use the KSE-100, the most representative index of the country, as a benchmark and augment the basic CAPM equation with the yield of PIBs $\left(\beta_{B}\right)$. The fit of the model deteriorates as we expand to the three- and four-factor variants of the simple CAPM. This could be for two reasons: (i) managers rely on portfolios represented by the benchmark index and do not diversify to small cap or past winner portfolios, and (ii) the part of their portfolio invested in debt instruments may have been misrepresented due to the missing bond index.

Islamic funds are governed by specific regulations and can only invest in the bonds and stocks of Shariah Complaint companies. Given that the country's Islamic bond market is still developing, the only reliable benchmark available for the period of analysis was the Dow Jones Islamic Market Pakistan Index, which we employed as a benchmark for our analysis. ${ }^{8}$ These funds were able to weather the recessionary storms better than conventional stock funds, but this also meant that they were unable to yield similarly high returns during the market's bull period. The surge in growth of Islamic funds continued even after the recession of 2008, which could be attributed to a growing religious orientation among people and their aversion to investment in fixed interest-yielding investment options. This category of funds thus occupies a niche that it can tap into and continue to grow.

\section{Conclusion}

Pakistan is a classic emerging market, still struggling to develop its capital market and a regulatory framework, and still experimenting to

\footnotetext{
${ }^{8}$ KMI-30, which tracks the 30 most liquid Shariah-compliant companies listed on the KSE, is another possible benchmark. However, data on this index is available only for periods after June 2008.
} 
find the right mix. These inefficiencies give managers an opportunity to earn abnormal returns that are not possible in developed markets. We find that all fund types consistently underperform relative to their respective benchmarks, which is not surprising given the evidence from across the world.

The negative Sharpe ratios sharply contradict those of other countries, signaling these funds' difficulty in providing returns over and above the risk-free rate. This can be attributed to the environment of rising interest rates in the country. Further, it would be interesting to evaluate how these alphas fare with management fees charged by the funds accounted for.

We have also found that stock funds in Pakistan consistently hold large cap stocks, but not more value-oriented stocks. The consistently negative or insignificant alphas signal the possible merit of the small number of index tracker funds in the country. However, it is important to consider that these funds will then also have to bear the consequences of extreme negative returns in a bearish market. Islamic funds, the fastest growing fund category and backed by people's religious affiliations are still struggling to find a stronghold and yield a steady return. They are presently a high-risk investment option, but have the potential to tap into a niche in the market. The presence of government-backed schemes that guarantee a constant income stream makes it difficult for other investment funds to compete; nonetheless, Islamic funds might appeal to investors who do not want a fixed return. 
Table 4: Fund-Wise Empirical Evidence

(January 2006-December 2010)

\begin{tabular}{|c|c|c|c|c|c|c|c|c|c|c|c|c|c|c|}
\hline & $\begin{array}{c}\text { (1) } \\
\text { Stock } \\
\text { Own10 }\end{array}$ & $\begin{array}{c}(2) \\
\text { Stock } \\
\text { KSE30 }\end{array}$ & $\begin{array}{c}(3) \\
\text { Stock } \\
\text { KSE100 }\end{array}$ & $\begin{array}{c}(4) \\
\text { Stock FF } \\
\text { Own10 }\end{array}$ & $\begin{array}{c}(5) \\
\text { Stock FF } \\
\text { KSE30 }\end{array}$ & $\begin{array}{c}(6) \\
\text { Stock FF } \\
\text { KSE100 }\end{array}$ & $\begin{array}{c}(7) \\
\text { Stock 4F } \\
\text { Own10 }\end{array}$ & $\begin{array}{c}(8) \\
\text { Stock 4F } \\
\text { KSE30 }\end{array}$ & $\begin{array}{c}(9) \\
\text { Stock 4F } \\
\text { KSE100 }\end{array}$ & $\begin{array}{c}(10) \\
\text { Income }\end{array}$ & $\begin{array}{c}\text { (11) } \\
\text { Multi- } \\
\text { Asset }\end{array}$ & $\begin{array}{c}\text { (12) } \\
\text { Multi- } \\
\text { Asset FF }\end{array}$ & $\begin{array}{c}\text { (13) } \\
\text { Multi- } \\
\text { Asset 4F }\end{array}$ & $\begin{array}{c}(14) \\
\text { Islamic }\end{array}$ \\
\hline$\alpha$ & $\begin{array}{r}-0.00321 \\
(-0.36)\end{array}$ & $\begin{array}{r}-0.00184 \\
(-0.35)\end{array}$ & $\begin{array}{r}-0.00771 \\
(-1.54)\end{array}$ & $\begin{array}{r}-0.0189^{* *} \\
(-2.05)\end{array}$ & $\begin{array}{r}-0.00881 \\
(-1.44)\end{array}$ & $\begin{array}{r}-0.0120^{* *} \\
(-2.05)\end{array}$ & $\begin{array}{r}-0.0204^{* *} \\
(-2.15)\end{array}$ & $\begin{array}{r}-0.0102 \\
(-1.60)\end{array}$ & $\begin{array}{r}-0.0137^{* *} \\
(-2.31)\end{array}$ & $\begin{array}{r}-0.00915^{* * * *} \\
(-4.75)\end{array}$ & $\begin{array}{r}0.000750 \\
(0.09)\end{array}$ & $\begin{array}{r}0.00491 \\
(0.49)\end{array}$ & $\begin{array}{r}0.00480 \\
(0.47)\end{array}$ & $\begin{array}{r}-0.00770 \\
(-1.95)\end{array}$ \\
\hline$\beta_{i}$ & $\begin{array}{r}0.231^{* * *} \\
(4.77)\end{array}$ & $\begin{array}{r}0.606^{* * *} \\
(13.69)\end{array}$ & $\begin{array}{r}0.731^{* * * *} \\
(13.49)\end{array}$ & $\begin{array}{r}0.213^{* * *} \\
(4.89)\end{array}$ & $\begin{array}{r}0.568^{* * *} \\
(12.67)\end{array}$ & $\begin{array}{r}0.688^{* * *} \\
(11.86)\end{array}$ & $\begin{array}{r}0.211^{* * *} \\
(4.82)\end{array}$ & $\begin{array}{r}0.565^{* * *} \\
(12.55)\end{array}$ & $\begin{array}{r}0.686^{* * *} \\
(11.92)\end{array}$ & $\begin{array}{r}-0.160^{* *} \\
(-2.81)\end{array}$ & $\begin{array}{r}0.417^{* * * *} \\
(7.51)\end{array}$ & $\begin{array}{r}0.433^{* * *} \\
(7.09)\end{array}$ & $\begin{array}{r}0.433^{* * *} \\
(7.02)\end{array}$ & $\begin{array}{r}0.273^{* * * *} \\
(6.40)\end{array}$ \\
\hline$\beta_{s}$ & & & & $\begin{array}{r}-0.323^{* * *} \\
(3.93)\end{array}$ & $\begin{array}{r}-0.140^{* *} \\
(2.60)\end{array}$ & $\begin{array}{r}-0.116^{* *} \\
(2.07)\end{array}$ & $\begin{array}{r}-0.318^{* * *} \\
(3.83)\end{array}$ & $\begin{array}{r}-0.137^{* *} \\
(2.53)\end{array}$ & $\begin{array}{r}-0.110^{*} \\
(1.97)\end{array}$ & & & $\begin{array}{r}-0.0223 \\
(-0.36)\end{array}$ & $\begin{array}{r}-0.0243 \\
(-0.38)\end{array}$ & \\
\hline$\beta_{H}$ & & & & $\begin{array}{r}0.0123 \\
(0.28)\end{array}$ & $\begin{array}{r}0.0148 \\
(0.54)\end{array}$ & $\begin{array}{r}0.0196 \\
(0.70)\end{array}$ & $\begin{array}{r}0.00776 \\
(0.17)\end{array}$ & $\begin{array}{r}0.0110 \\
(0.40)\end{array}$ & $\begin{array}{r}0.0142 \\
(0.51)\end{array}$ & & & $\begin{array}{r}0.0192 \\
(0.65)\end{array}$ & $\begin{array}{r}0.0180 \\
(0.60)\end{array}$ & \\
\hline$\beta_{P}$ & & & & & & & $\begin{array}{r}-0.0987 \\
(-0.72)\end{array}$ & $\begin{array}{r}-0.0712 \\
(-0.86)\end{array}$ & $\begin{array}{l}-0.118 \\
(-1.38)\end{array}$ & & & & $\begin{array}{r}-0.0250 \\
(-0.27)\end{array}$ & \\
\hline$\beta_{B}$ & & & & & & & & & & & $\begin{array}{c}-18.39^{*} \\
(-2.00)\end{array}$ & $\begin{array}{r}-20.23^{* *} \\
(-2.04)\end{array}$ & $\begin{array}{r}-20.54^{* *} \\
(-2.04)\end{array}$ & \\
\hline $\begin{array}{l}\text { Adj. } \\
\mathrm{R}^{2}\end{array}$ & 0.289 & 0.789 & 0.757 & 0.422 & 0.801 & 0.767 & 0.417 & 0.806 & 0.771 & 0.107 & 0.517 & 0.506 & 0.497 & 0.408 \\
\hline
\end{tabular}

KSE $=$ Karachi Stock Exchange

FF: Fama-French three-factor model, 4F: Carhart model.

$* / * * / * *$ indicate significance at the $90 / 95 / 99$ percent confidence level, respectively, with $t$ statistics in parentheses.

Source: Authors' calculations. 


\section{References}

Afza, T., \& Rauf, A. (2009). Performance evaluation of Pakistani mutual funds. Pakistan Economic and Social Review, 47(2), 199-214.

Białkowski, J., \& Otten, R. (2011). Emerging market mutual fund performance: Evidence for Poland. North American Journal of Economics and Finance, 22(2), 118-130.

Carhart, M. (1997). On persistence in mutual fund performance. Journal of Finance, 52(1), 57-82.

Carhart, M., Carpenter, J., Lynch, A., \& Musto, D. (2002). Mutual fund survivorship. Review of Financial Studies, 15, 1439-1463.

Cesari, R., \& Panetta, F. (2002). The performance of Italian equity funds. Journal of Banking and Finance, 26, 99-126

Cuthbertson, K., Nitzsche, D., \& O'Sullivan, N. (2008). UK mutual fund performance: Skill or luck? Journal of Empirical Finance, 15(4), 613634.

Eling, M., \& Faust, R. (2010). The performance of hedge funds and mutual funds in emerging markets. Journal of Banking and Finance, 34, 1993-2009.

Fama, E. F., \& French, K. R. (1993). Common risk factors in the returns on stocks and bonds. Journal of Financial Economics, 33(1), 3-56.

Fama, E. F., \& French, K. R. (2010). Luck versus skill in the cross-section of mutual fund returns. Journal of Finance, 65(5), 1915-1947.

Huij, J., \& Post, T. (2011). On the performance of emerging market equity mutual funds. Emerging Markets Review, 12, 238-249.

Jensen, C. M. (1968). The performance of mutual funds in the period 1945-1964. Journal of Finance, 23(2), 389-416.

Klapper, L., Sulla, V., \& Vittas, D. (2004). The development of mutual funds around the world. Emerging Markets Review, 5, 1-38. 
Lai, M. M., \& Lau, S. H. (2010). Evaluating mutual fund performance in an emerging Asian economy: The Malaysian experience. Journal of Asian Economics, 21(4), 378-390.

Mahmud, M., \& Mirza, N. (2010). Volatility dynamics of Karachi Stock Exchange. Manuscript submitted for review.

Mutual Funds Association of Pakistan. (2010). Mutual funds yearbook 200910. Karachi. Author.

Nazir, M. S., \& Nawaz, M. M. (2010). The determinants of mutual fund growth in Pakistan. International Research Journal of Finance and Economics, 54, 75-84.

Otten, R., \& Bams, D. (2004). How to measure mutual fund performance: Economic versus statistical relevance. Accounting and Finance, 44, 203-222.

Shah, S. M., \& Hijazi, S. T. (2005). Performance evaluation of mutual funds in Pakistan. Pakistan Development Review, 44(4), 863-876.

Sharpe, W. F. (1966). Mutual fund performance. Journal of Business, 39, 119-138.

Sipra, N. (2006). Mutual fund performance in Pakistan, 1995-2004 (Working Paper No. 06-45). Lahore, Pakistan: Centre for Management and Economic Research. 